\title{
Impact of China's WTO Accession on East Asia
}

\author{
Elena Ianchovichina ${ }^{1}$ and Terrie Walmsley
}

April 2003

\begin{abstract}
$^{2}$
China's WTO accession will have major implications for China and present both opportunities and challenges for East Asia. We assess the possible channels through which China's accession to the WTO could affect East Asia and quantify these effects using a dynamic computable general equilibrium model. China will be the biggest beneficiary of accession, followed by the industrialized and newly industrializing economies (NIEs) in East Asia. However, their benefits are small relative to the size of their economies and to the vigorous growth projected to occur in the region over the next 10 years. By contrast, developing countries in East Asia are expected to incur small declines in real GDP and welfare as a result of China's accession, mainly because with the elimination of quotas on Chinese textile and apparel exports to developed countries China will because a formidable competitor in areas in which these countries have comparative advantage.
\end{abstract}

With WTO accession China will increase its demand for petrochemicals, electronics, machinery, and equipment from Japan and the Newly Industrializing Economies (NIEs), and farm, timber, energy products, and other manufactures from the developing East Asian countries. New foreign investment is likely to flow into these expanding sectors. The overall impact on foreign investment is likely to be positive in the NIEs, but negative for the less developed East Asian countries as a result of the contraction of these economies' textile and apparel sector. As China becomes a more efficient supplier of services or a more efficient producer of high-end manufactures, its comparative advantage will shift into higher-end products. This is good news for the poor developing economies in East Asia, but implies that the impact of China's WTO accession on the NIEs may change to include heightened competition in global markets.

JEL classification: F11, F15

Keywords : China, WTO accession, regional impact, East Asia, general equilibrium

\footnotetext{
${ }^{1}$ Elena Ianchovichina is an economist at PRMEP, the World Bank, $1818 \mathrm{H}$ Street, NW, Washington DC 20043, tel. (202) 458-8910, fax: (202) 522-2530, email: eianchovichina@worldbank.org. Terrie Walmsley is a faculty associate at the Center for Global Trade Analysis, Purdue University and a lecturer in the Department of Economics, Sheffield University, 9 Mappin Street, S1 4DT Sheffield, UK, tel. 44-114-2223414, fax: 44-114-222-3458, email: t.walmsley@sheffield.ac.uk. The authors gratefully acknowledge helpful comments from Kathie Krumm, William Martin, Lu Ding, Nattapong Thongpakde, Sethaput Suthiwart Narueput, and participants at seminars held at the Institute for Southeast Asian Studies of the National University of Singapore, the Thailand Development Research Institute in Bangkok, and the World Bank office in Jakarta. Any remaining errors or omissions are the authors' responsibility. The opinions expressed in this paper are solely those of the authors and not of the World Bank, its Executive Directors, or the countries they represent.

${ }^{2}$ This paper - a product of PREM, Economic Policy - was supported by a Regional and Network Research Grant.
} 


\section{Introduction}

China's WTO accession will have major implications for China and present both opportunities and challenges for the East Asian economies. A number of factors highlight the importance of China's deeper integration into the world economy. The Chinese economy is large in absolute terms. Purchasing power measures suggest that China is the second largest economy in the world, constituting half of the Asian economy and 11 percent of the world economy in 1996 compared to 21 percent for the U.S. (IMF, 1997). ${ }^{3}$ China's trade has grown rapidly with the share of exports almost tripling, and that of imports more than doubling over the period 1990-1996. ${ }^{4}$ In terms of merchandise trade, last year China ranked as the $7^{\text {th }}$ largest exporter and the $8^{\text {th }}$ largest importer in the world. ${ }^{5}$ Despite the fact that China's capital account is not fully convertible, China is an important player, both as a recipient and a lender, in global capital markets. By the midnineties, China had become the second largest host country for foreign direct investment (FDI) after the U.S., ${ }^{6}$ the $8^{\text {th }}$ largest capital supplier in the world and the largest one among developing countries (World Bank, 1997). ${ }^{7}$ Due to capital account restrictions, China's absorption of portfolio investment is still limited. However, China's role as a capital supplier is likely to expand given continued growth, high saving ratio and the gradual relaxation of capital controls.

With WTO accession, China will continue the process of opening its markets to other countries' exports and improving its business climate. This will lower input and transaction costs and benefit both China and its trading partners. Increased exports from China to the region will also lower the import prices of its trading partners and improve their competitiveness. However, accession will also present challenges. Countries that produce similar products will face increased competition for market share in third markets. Accession is likely to increase China's attractiveness as a destination for foreign investment, leading to concerns that investment may be diverted away from other countries in the region towards China.

The complexity of the anticipated changes in China, the lack of clarity as to what the counterfactual is, and the uncertainty associated with the policy response in China and elsewhere ${ }^{8}$ make the task of assessing the impact of China's WTO accession on the East

\footnotetext{
${ }^{3}$ If measured at current exchange rates (2001) China is important, but not dominant. Its current income is 9 times smaller than the GDP of the US and accounts for only 3.7 percent of world GDP and 4.4 percent of total trade (Source: World Bank).

${ }^{4}$ The rapid increase in China's exports occurred over two stages - with the initial opening (1980-1985), when trade grew faster than GDP, the trade share increased from $0.7 \%$ to $2 \%$ of world trade, and with trade reform after 1987, when both trade and GDP grew and the trade share rose to $4 \%$ in 2000 . China's trade performance over the period 1970-2000 is consistent with the performance of other Asian economies (Source: Goldman Sachs Research).

5 Source: Customs General Administration, People's Republic of China.

${ }^{6}$ It is difficult to judge the accuracy of the FDI data as they reflect 'round-tripping' investments undertaken from China to take advantage of concessions enjoyed only by foreign investors.

7 These outflows do not include flows through Hong Kong (China).

${ }^{8}$ The outcome in other East Asian countries will depend to a large degree on the trade and investment policies adopted by these countries in response to the post-accession changes in China.
} 
Asian economies a challenging one. Thus, our primary objective is to provide a systematic discussion of the main channels by which China's WTO accession will have an impact on regional economies, and then provide initial quantitative assessment of the impact using a multi-region dynamic general equilibrium framework.

This approach is well-suited for the problem at hand since it offers a systematic way for determining the likely pattern of changes in factor and commodity prices, and production around the world in response to an exogenous shock while taking into account the complex sectoral and regional linkages over time. The general equilibrium approach has been used to quantify the impact of China's WTO accession in a number of studies. ${ }^{9}$ Detailed studies focusing on specific sectors and issues have also been conducted ${ }^{10}$ and a number of papers have given special attention to the impact of China's WTO accession on the countries in East Asia. ${ }^{11}$

This paper improves upon the earlier work by taking into account duty drawbacks in China and Vietnam, ${ }^{12}$ constructing a baseline that reflects most recent growth projections $^{13}$ and major trade commitments in the region, ${ }^{14}$ using China's final WTO offer and recent estimates of nominal rates of protection and subsidies in agriculture, ${ }^{15}$ representing the efficiency gains in the automobile sector induced by the WTO reform

\footnotetext{
${ }^{9}$ See Lejour (2000), Fan and Li (2000), Li et al (2000), McKibbin and Tang (2000), Ianchovichina and Martin (2001, 2002), Wang (2002), Walmsley and Hertel (2001), Walmsley et al. (2001), Deutsche Bank (2001) (see also Gilbert and Wahl (2000) for a survey).

${ }^{10}$ Huang and Rozelle (2002) and Anderson, Huang and Ianchovichina (2002) analyzed agricultural policy reforms as part of China's WTO accession and their impact in light of existing distortions to agricultural incentives in China. Francois and Spinanger (2002) studied the impact of WTO reforms on the automobile sector, while Pangestu and Mrongowius (2002), Bhattasali (2002), Wenping and Findlay (2002) analyzed the impact of WTO reforms on China's telecoms, financial and logistics sectors, respectively. Sicular and Zhao (2002) and Hussain (2002) focused on labor market issues and the design of safety nets, respectively. Hertel, Fan and Wang (2002), and Chen and Ravallion (2002) conducted analysis of the impact of WTO accession on different households and poverty in China. Mattoo (2001) discussed China's WTO commitments in the service sectors, Maskus (2001) - the intellectual property rights, and Messerlin (2002) - the antidumping and safeguard provisions in China's accession package.

${ }^{11}$ See, for example, Lejour (2000), Li et al. (2000), Wang (2001), Ianchovichina and Martin (2001), and Deutsche Bank (2001).

${ }^{12}$ Lejour (2000) acknowledges the importance of duty exemptions but implements them as simple proportionate cuts in tariffs across all sectors and as duty exemptions on imports used in production, instead of exemption on imports used in the production of exports. This introduces bias in his results.

${ }^{13}$ Source: World Bank.

${ }^{14}$ These include the Uruguay Round, the Agreement on Textiles and Clothing, AFTA, and the reform in China prior to 2001. Ianchovichina and Martin (2001) incorporate duty exemptions on imports used in the production of exports but ignore the impact of AFTA in the baseline.

${ }^{15}$ Lejour (2000) assumed a simple 50\% cut in all tariffs that introduced distortions into the sectoral liberalization story. It is also misleading to compare statutory tariffs and post-accession rates in order to assess the extent of liberalization in agriculture as part of China's WTO accession. Recent research (Huang and Rozelle, 2002) reveals that nominal protection rates on important agricultural commodities (rice, vegetables and fruits, livestock and meat) were negative in 2001 and are likely to remain unchanged in the post-accession period. Consequently, the reduction in agricultural protection is likely to be far less than presented in earlier studies. Nonetheless, greater scope for imports in China are likely for a range of agricultural products (wheat, oilseeds, sugar and dairy products) that are protected mainly by tariffs, scheduled to be reduced substantially, and cotton and feedgrains, where export subsidies are ruled out. These important findings are not incorporated in earlier studies.
} 
process, ${ }^{16}$ and liberalization in cross-border trade in services. ${ }^{17}$ Throughout the paper we compare and supplement our findings with results from this literature. We extend the literature by looking at the impact of accession induced technological change in China on the East Asian region.

The paper is organized as follows. Section 2 provides a qualitative analysis of the impact of WTO accession on East Asia. Section 3 discusses the methodology and simulation design and provides a quantitative assessment of the impact of accession on individual country's output, exports, investment flows and welfare. Section 4 discusses the impact of accession induced productivity gains in China on the countries in East Asia. Section 5 offers some concluding remarks.

\section{Impact of WTO Accession on East Asia: A Qualitative Assessment}

We identify several main channels through which China's WTO accession will affect the economies in East Asia: (1) increased access to China's domestic market; (2) improved competitiveness; (3) competition with China in third markets; (4) expansion of foreign investment in China and, potentially, outward foreign investment from China; (5) transparency and predictability of trade policy; (6) entry of a major developing country to the WTO.

\section{Increased access to China's large market}

China has been a powerful driver of growth in East Asia - spurring growth not only in the newly industrialized economies, but also in the developing countries of East Asia. In 1997, more than 60 percent of China's imports were sourced from other countries in East Asia. ${ }^{18}$ However, in the nineties, ASEAN countries' exports to China grew by 390 percent and these countries' share in China's total imports rose from a little below 6 percent in 1990 to 9 percent in $1999 .{ }^{19}$

Looking ahead, China is expected to continue to be a driver of growth in East Asia as it becomes a much bigger market for its trading partners following accession to the WTO. ${ }^{20}$ In many sectors China's WTO accession only adds a little to the already vigorously projected growth of these markets. ${ }^{21}$ Nevertheless, accession will lead to significant changes. In services, China has made commitments to provide national treatment to

\footnotetext{
${ }^{16}$ Francois and Spinanger (2002) estimates that tariff reform as part of WTO accession could generate as much as a 20 percent increase in total factor productivity in the automobile sector affecting particularly assembly operations. None of the studies looking at the regional impact of China's WTO accession consider the reform-induced restructuring of the automobile sector.

${ }^{17}$ The method adopted here follows Francois and Spinanger (2002). Most studies have abstracted from the impact of China's WTO accession on cross-border trade in services.

${ }_{18}^{18}$ Source: Version 5 GTAP data (Dimaranan and McDougall, 2002).

${ }^{19}$ Source: UN Comtrade System.

${ }^{20}$ With assumptions of higher growth rate in China than in other developing countries, China's share of world trade is expected to double by 2007 and surpass that of Japan, but be still much lower than that of US and the EU (Ianchovichina and Martin, 2002).

${ }^{21}$ Growth in China has been fueled by years of serious economic reform. See Tables 5, A.5, and A.6 in Ianchovichina and Martin (2002).
} 
foreign-funded firms and greater opportunities for exporters of services. $^{22}$ In manufactures, China has committed to abolish non-tariff barriers and reduce tariffs from 13.3 percent in 2001 to 6.8 percent $^{23}$ by the end of the implementation period. In agriculture, China's imports are projected to grow, though this growth is much smaller than projected in earlier studies since protection on many farm products is expected to remain virtually unchanged by the end of the implementation period. ${ }^{24}$

Growth in the region will also be stimulated by increased demand in China's major trading partners that benefit directly from China's accession. Therefore, the East Asian developing countries will export more not only to China, but also to Japan, Tawain (China) and the rest of the Newly Industrializing Economies (NIEs). Both the direct and indirect effects of increased access to China's markets will be important determinants of regional trade.

\section{Improved competitiveness}

China's accession to the WTO will be accompanied by a reduction in protection that will lower its export prices and increase China's appeal as an efficient supplier. China's preaccession reforms have already improved the competitiveness of Chinese exports and have benefited its closest trading partners. Trade intensity indexes for 1985 and 2001 suggest that trade between China and individual East Asian economies has intensified sharply since $1985 .^{25}$ Thus, most East Asian economies are expected to benefit from further cuts in export prices as China continues to implement WTO related reform over the next few years. The benefits to these countries will be both in terms of increased output and welfare as these countries source cheaper imports from China and use them as intermediate inputs in their production processes. However, to realize these benefits, countries will have to resist protectionist pressures, which have been growing in a number of countries.

\section{Increased competition in third markets}

Competition with China in third markets will intensify as a result of China's accession to the WTO. This will present a challenge for many countries, especially those that have similar comparative advantage in labor intensive goods.

South East Asia competes with China in world markets for manufactures, especially labor intensive products, and increasingly higher value added products, such as semi conductors and other high technology products. Competition has led to unit price declines, but thus far other developing East Asian exporters have maintained their market

\footnotetext{
${ }^{22}$ These commitments represent the most significant part of China's accession package (Mattoo, 2001).

${ }^{23}$ These are weighted average tariffs computed using trade weights for 2001 (see Ianchovichina and Martin, 2002).

${ }^{24}$ See Huang and Rozelle (2002).

${ }^{25} \mathrm{Ng}$ and Yeats (2002).
} 
shares in the U.S and Japan. ${ }^{26}$ The aggregate picture, however, hides the story for individual sectors. ASEAN maintained market share for textiles and apparel in the quotaconstrained US market, albeit at the expense of falling unit prices. However the South East Asian countries lost market share in textiles and apparel in Japan, where China's exports of textiles and apparel are not quota constrained.

A number of reasons suggest that competition will intensify with China's WTO accession. Accession will lead to the abolition of quotas on Chinese textiles and apparel exports to the U.S. and the EU in 2005. ${ }^{27}$ This implies that China will become a formidable competitor especially in the apparel market. ${ }^{28}$ The effect of tariff reductions on the real exchange rate will lower the costs of both trade and non-traded inputs for China's manufactures. This will make China's products more competitive, putting pressure on the price of competing products elsewhere. China has a vast labor force, including a large stock of underemployed agricultural workers, spread over vast geographical areas that differ in stages of economic development. China also has much lower labor cost per unit of output, not only relative to developed countries, but also compared to most developing countries. This suggests that cheap labor supply will last for a long time regardless of China's rate of growth. ${ }^{29}$

\section{Changes in Investment Patterns}

WTO accession will increase foreign investment in China as trade liberalization lowers production costs and the price of capital goods, and increases the rental rates, resulting in rising returns to capital in China. ${ }^{30}$ WTO accession will ensure that China adheres to the general principle of non-discrimination, ${ }^{31}$ which will boost investment as it implies lower transaction costs, increased imports, and increased sales and profits of foreign invested companies. Meanwhile, the liberalization of rules on investment should ease flows of FDI into previously restricted sectors such as services.

China's accession is also likely to set off changes in regional trade and production patterns whose effects will be felt over the longer term. The issue for other East Asian economies is whether their own foreign investment inflows will increase or decrease as a result. It is difficult to answer this question since much will depend on the policy responses of individual countries. In addition, a number of factors will work simultaneously to determine the net regional impact of China's WTO accession on investment flows. While countries that lose competitiveness may see declining returns to

\footnotetext{
${ }^{26}$ In the U.S., China and ASEAN gained market share at the expense of Japan, Tawain (China), and Korea. In Japan, China and ASEAN captured market share at the expense of the U.S. and Japanese firms (Andy Xie, Morgan Stanley Research, 2002).

${ }^{27}$ China will be subject to additional textile safeguard quotas until 2007, but these will be applicable for only one year at a time, unlike the existing quotas which were put in place for an indefinite period of time.

${ }^{28}$ This is a consensus finding supported by Ianchovichina and Martin (2001, 2002), Deutsche Bank (2001), and Wang (2002).

${ }^{29}$ Wang (2002).

${ }^{30}$ McKibbin and Tang (2000) and Walmsley, Hertel and Ianchovichina. (2002) discuss in detail the effect of trade and financial reform in China on rates of return to capital and foreign investment.

${ }^{31}$ Bhattasali, Shantong and Martin (2002).
} 
capital and foreign investment diverted to China, several effects are likely to counteract this negative impact on foreign investment.

Whereas in the past China used to draw heavily on the overseas Chinese community as a source of FDI, with accession China will be able to draw on the global capital markets both for FDI and portfolio investment. Thus, competition between China and other countries in East Asia for FDI may actually weaken.

Increased productivity and trade liberalization in China both increase the country's demand for imports and raise investment and welfare in China's trading partners. Martin (1993) shows that a productivity shock in manufactures and services, for which there is a lot of two-way trade, is more likely to raise welfare in country's trading partners than is trade liberalization. Given the substantial productivity gap that exists between local and foreign firms, the new FDI flows are very likely to raise China's productivity. In apparel and footwear (textiles), for example, the adoption of foreign technology raises productivity by $30-62 \%$ in collective enterprises and $20-59 \%$ in state enterprises. $^{32}$ This implies that the technological advance accompanying China's WTO accession will improve the country's competitiveness, increase the country's demand for imports, and perhaps raise investment levels in countries supplying these imports.

Investment liberalization in China will make it possible for multinational firms to further rationalize their production processes within East Asia. The relief of local content requirements under Trade-Related Investment Measures (TRIMs) will encourage these firms to relocate some segments of their production from China to other countries in the region. In some sectors, China's neighbors may receive FDI flows that complement those going to China. The scope for export specialization will vary with the degree of complementarity between China and other countries of East Asia. Its current comparative advantage in labor-intensive products suggests that there is more scope for export specialization vis a vis the newly industrializing economies than vis a vis the developing East Asian countries.

As FDI creates more backward and forward linkages among countries in the region, the competitiveness of Asian products will depend not only on the competitiveness of the country that exports the final product, but also on those neighboring countries that contribute various components at different stages of the production process. This will create an incentive to direct investment to different countries that are part of the regional production network.

Finally, the determinants of FDI are evolving over time. Agglomeration effects are becoming more important relative to traditional determinants of FDI such as market size and labor costs. ${ }^{33}$ China's comparative advantage may also change appreciably after WTO accession. ${ }^{34}$ Over time, China is also likely to shift and extend its comparative

${ }^{32}$ Claro (2001).

${ }^{33}$ UNCTAD (2002).

${ }^{34}$ All East Asian economies saw increases in the share of manufactured exports during the first half of the 1990s and all saw changes in the structure of manufactured exports. In the 1990s, the NIEs increased their 
advantage into higher-end products as the result of trade-induced productivity gains ${ }^{35}$ and savings in transaction costs from the reforms spurred by WTO accession. This implies that the impact of China's WTO accession on the NIEs may change to include heightened competition in global markets.

\section{Transparency and predictability of trade policy}

China's trading partners are going to benefit from the increased transparency and predictability of trade policy as China follows general WTO policy rules and a number of specific commitments. ${ }^{36}$ The general WTO policy rules include among other things the need to publish trade rules and regulations. The specific commitments involve uniform application of the trade regime, independent judicial review and a mechanism to bring problems of local protectionism to the attention of the central government. This means that access to China's market will be secured and disputes will be resolved following international standards. This will be an important benefit to China's trading partners.

\section{Entry of a major developing country to the WTO}

China could share its experience in the design of institutions that work effectively in lowincome developing countries. ${ }^{37}$ This will help countries in the region that are not yet WTO members but are planning to join the organization to avoid problems from adoption of practices that work well in a developed country context, but not in a developing country context. ${ }^{38}$ In addition, China has a wide range of market access interests. Just like other developing countries, it faces relatively high tariff barriers in quite a wide range of export products, such as textiles and clothing, and agricultural exports. After accession to the WTO, the developing economies in East Asia and elsewhere could gain from cooperation with China to reduce these barriers.

\section{Impact of WTO Accession on East Asia: A Dynamic Computable General Equilibrium Analysis}

The previous section illustrated some of the effects of China's WTO accession and showed that their direction will be mixed. Some of these effects will be unequivocally positive or negative for all countries in East Asia. Others will differ in their impact depending on the countries' stage of development, current trade patterns, the degree to which countries can alter their import mix and the mix of domestic and imported products, and their comparative advantages. ${ }^{39}$ To discern the likely impact of China WTO accession on other East Asian economies and quantify these effects we conduct analysis using a dynamic general equilibrium approach.

share of electronics and information technology products and China increased its share of electronics and telecommunications exports.

${ }^{35}$ This issue is explored in detail in section 4.

${ }^{36}$ See Bhattasali, Shantong, Martin (2002).

${ }^{37}$ See Martin and Ianchovichina (2001).

${ }^{38}$ See Finger and Schuler (2000).

${ }^{39}$ The impact will also depend on the policy response in China and rest of East Asia. However, we do not consider such alternative policies here. 


\section{Methodology}

The general equilibrium modeling provides a comprehensive assessment of the reform process in China in a global context. The analysis relies on the dynamic version of GTAP (GTAP-Dyn), a global general equilibrium model, ${ }^{40}$ modified to capture duty exemptions for imports used in the production of exports in China and Vietnam. ${ }^{41}$ These export processing arrangements are important for the analysis since they imply that the economies of China and Vietnam are much more open then suggested by statutory tariff rates. This in turn implies a much smaller impact of WTO accession on the Chinese and other economies than found by studies that ignore duty drawbacks.

The dynamic GTAP model has a sophisticated representation of consumer demands via a constant difference of elasticities (CDE) functional form and a supply side that emphasizes the role of intersectoral factor mobility in the determination of industry output. Product differentiation between imports and domestic goods, and imports by region of origin allows for two-way trade in each product category, depending on the ease of substitution between products from different regions. In each region, a single regional household allocates income from land, skilled and unskilled labor, financial assets, and a natural resource endowment across private and government consumption, and saving according to a Cobb Douglas utility function. Firms supply commodities to both the domestic and export markets, while minimizing production costs.

The investment theory in the model allows us to link economic activity over time while keeping track of endogenous regional capital stocks and financial wealth, ${ }^{42}$ international investment and income flows. The theory respects the empirical regularity that regions tend to invest primarily in assets located in their domestic economy. A smaller portion of investment comes from abroad and the theory offers a disequilibrium approach for allocating this investment across regions. Investors respond to expected rates of return and act so as to eliminate errors in their expectations gradually over time. In the process of adjustment, investors gradually eliminate any differences in the rates of return across regions that might exist in the short run by reallocating capital from regions with lower rates of return to regions with higher rates of return. ${ }^{43}$ This leads to equalization of rates of return across regions only in the long run. ${ }^{44}$

\footnotetext{
${ }^{40}$ Hertel (1997) provides a comprehensive description of the GTAP model and data, while Ianchovichina and McDougall (2001) document its dynamic version.

${ }^{41}$ The GTAP model with duty drawbacks is presented in Ianchovichina (2003).

${ }^{42}$ Unlike capital, land, labor and the natural resource endowment are exogenous. All factor inputs are fully employed, immobile across regions, and with the exception of land and the natural resource input, are perfectly mobile across sectors. The model captures how differences in relative rates of factor accumulation interact with differential sector intensities giving rise to the so-called 'Rybczynski' effect.

${ }^{43}$ This way of determining changes in FDI flows captures only the substitution effect of allocating FDI, i.e. the relocation of incremental FDI from regions with falling rates of return to regions with rising rates of return.

${ }^{44}$ The disequilibrium approach is also necessary to reconcile the theory of investment with observed reality. In many cases actual investment, as reported in the national statistics, does not correspond to that predicted by theory. For example, observed rates of return may be very low while observed investment is high. Such discrepancies can be rectified in one of two ways: the data can be altered so that theory and data
} 
Financial assets represent claims on earnings from regional physical capital, which is owned by both domestic and foreign households via a global trust. ${ }^{45}$ In the model, the allocation of investment assumes that the shares of domestic and foreign investments are held constant, subject to the adding-up constraints required to ensure regional saving and investment constraints. Explicit modeling of the ownership of regional investment allows us to track the accumulation of wealth by foreigners, thereby ascertaining how China's accession to the WTO might affect foreign investment and ownership in each region. Moreover, the income accruing from the foreign and domestic ownership of assets can then be appropriately incorporated into regional income, and hence into the calculation of welfare, both for China and for all other regions.

\section{Table 1. China's Average Tariff Rates (\%)}

\begin{tabular}{lccccccccccc}
\hline \multicolumn{1}{c}{ Sectors } & $\mathbf{1 9 9 7}$ & $\mathbf{1 9 9 8}$ & $\mathbf{1 9 9 9}$ & $\mathbf{2 0 0 0}$ & $\mathbf{2 0 0 1}$ & $\mathbf{2 0 0 2}$ & $\mathbf{2 0 0 3}$ & $\mathbf{2 0 0 4}$ & $\mathbf{2 0 0 5}$ & $\mathbf{2 0 0 6}$ & $\mathbf{2 0 1 0}$ \\
\hline Food grains & 10.6 & 9.8 & 9.1 & 8.3 & 7.6 & 7.6 & 7.6 & 7.6 & 7.6 & 7.6 & 7.6 \\
Feed grains & 28.0 & 29.0 & 30.0 & 31.0 & 32.0 & 32.0 & 32.0 & 32.0 & 32.0 & 32.0 & 32.0 \\
Vegetables-fruits-nuts & -8.0 & -7.0 & -6.0 & -5.0 & -4.0 & -4.0 & -4.0 & -4.0 & -4.0 & -4.0 & -4.0 \\
Oil seeds & 28.0 & 26.0 & 24.0 & 22.0 & 20.0 & 17.2 & 14.3 & 11.5 & 8.7 & 5.8 & 3.0 \\
Sugar & 42.0 & 41.5 & 41.0 & 40.5 & 40.0 & 36.7 & 33.3 & 30.0 & 26.7 & 23.3 & 20.0 \\
Plant fibers & 17.0 & 17.0 & 17.0 & 17.0 & 17.0 & 17.5 & 18.0 & 18.5 & 19.0 & 19.5 & 20.0 \\
Livestock-Meat-Dairy & -8.9 & -8.2 & -7.4 & -6.7 & -5.9 & -6.3 & -6.6 & -6.9 & -7.2 & -7.5 & -7.8 \\
Beverages-tobacco & 63.2 & 58.9 & 54.5 & 50.2 & 44.6 & 39.9 & 35.1 & 30.3 & 25.5 & 20.8 & 16.0 \\
Other food & 34.8 & 35.2 & 35.5 & 35.9 & 35.3 & 31.0 & 26.7 & 22.4 & 18.1 & 13.8 & 9.5 \\
Wood products & 10.8 & 10.5 & 10.2 & 9.8 & 9.5 & 8.5 & 7.5 & 6.5 & 5.5 & 4.6 & 3.6 \\
Extract & 0.2 & 0.3 & 0.3 & 0.3 & 0.5 & 0.5 & 0.4 & 0.4 & 0.4 & 0.3 & 0.3 \\
Textiles & 25.1 & 24.2 & 23.3 & 22.4 & 20.7 & 18.8 & 16.8 & 14.8 & 12.8 & 10.8 & 8.8 \\
Wearing apparel & 31.8 & 30.0 & 28.2 & 26.4 & 23.4 & 22.0 & 20.7 & 19.3 & 18.0 & 16.6 & 15.3 \\
Light manufactures & 12.1 & 12.1 & 12.1 & 12.2 & 11.7 & 11.1 & 10.5 & 9.8 & 9.2 & 8.6 & 8.0 \\
Processing industries & 12.0 & 12.0 & 12.0 & 12.0 & 11.7 & 10.9 & 10.1 & 9.2 & 8.4 & 7.6 & 6.8 \\
Autos & 34.4 & 34.9 & 35.4 & 35.8 & 32.0 & 29.0 & 26.0 & 23.0 & 20.0 & 17.0 & 14.0 \\
Electronics & 11.9 & 11.5 & 11.0 & 10.6 & 10.3 & 9.0 & 7.6 & 6.2 & 4.8 & 3.4 & 2.0 \\
Other manufactures & 13.2 & 13.2 & 13.2 & 13.2 & 12.9 & 11.9 & 10.8 & 9.8 & 8.7 & 7.7 & 6.7 \\
\hline Surc: Aund
\end{tabular}

Source: Authors's calculations based on version 5 GTAP data (www.gtap.org), World Bank, and data from CDS consulting. These tariff rates are trade weighted, applied, statutory rates..

We use version 5 GTAP database, aggregated into 20-regions and 22-sectors, shown in Appendix Table A1. The GTAP data base is supplemented with foreign income data from

are consistent; or alternatively, the theory can be modified to more accurately reflect the world. In GTAPDyn the latter method is used.

${ }^{45}$ The global trust collects all the regional saving allocated to foreign investment, then allocates it across regions to investment. It is a fictitious agent invented to simplify the need for data in the global model. Without the global trust a region's saving would need to be allocated directly to foreign investment by region. As a result bilateral data on foreign investment would be required (nxn data values, where $\mathrm{n}$ equals the number of regions). The use of the global trust minimizes the data required to regional saving invested abroad and total foreign investment in each region ( $2 \mathrm{n}$ data values). 
the IMF Balance of Payments statistics in order to track international capital mobility and foreign wealth.

We assesses the regional impact of China's WTO accession against a baseline that depicts the growth of the world economy over the period 1997-2010, ${ }^{46}$ the implementation of the Uruguay Round (UR), the Agreement on Textiles and Clothing, AFTA and the reform in China prior to 2001. The accession scenario represents reform of China's agriculture, manufacturing and services. Reform in agriculture includes tariff reform (Table 1) and the removal of export subsidies on feed grains and cotton. ${ }^{47}$ Reform of China's manufacturing encompasses the removal of quotas on China's textiles and apparel exports to the European Union and North America, ${ }^{48}$ tariff reform (Table 1) and the restructuring of China's automobile sector. ${ }^{49}$ Services liberalization represents the removal of non-tariff barriers on cross-border trade. ${ }^{50}$

\section{Impact on Japan and the NIEs in East Asia}

China will be the biggest beneficiary of accession to the WTO, ${ }^{51}$ gaining around US\$ 10 billion $^{52}$ or about 1 percent of China's GDP in 2001. ${ }^{53}$ Japan and the newly industrialized economies in East Asia will also benefit from China's accession to the WTO (Table

\footnotetext{
${ }^{46}$ Appendix Tables A2 and A3 show baseline growth rates for GDP and gross domestic investment (GDI).

${ }^{47}$ Huang and Rozelle (2002) estimate that subsidies on feed grains and cotton are 32 percent and 10 percent, respectively.

${ }^{48}$ Unlike most other developing countries - members of the GATT 1947, China was excluded from the Uruguay Round Agreement on Textiles and Clothing (ATC). Therefore, China has not benefited from the increase in quotas provided for under this agreement. This has put pressure on the transaction prices of these quotas, which are equivalent to an export tax of the same magnitude. In this paper we use estimates of the 2001 export tax equivalents in Ianchovichina and Martin (2002). In the US the 2001 quotas on Chinese textiles and apparel are equivalent to an export tax of 11 and 15 percent, respectively, while in the EU those are 12 and 15 percent respectively. With accession China will benefit from the abolition of these quotas by 2005. Based on the experience with ATC under the Uruguay Round of the WTO (Spinanger, 1999), quota removal will be back-loaded with the bulk of the impact not felt until the last two years.

49 The method adopted here follows Francois and Spinanger (2002).

${ }^{50}$ Francois and Spinanger (2002) provide estimates of the tariff equivalents of the non-tariff barriers to cross-border trade in services in China and Tawain (China) before and after accession. From these estimates cuts in tariff equivalents on direct trade in services are computed as documented in Hertel, Walmsley, and Itakura (2001). For China, the resulting annual cuts are 0.2 for trade and transport, 0.8 for communications, 2.2 for commercial services, 1.7 for other services. For Tawain (China), the resulting cuts are 0.3 for trade and transport, 0.4 for communications, 0.7 for commercial services, and 1.2 for other services.

${ }^{51}$ This result is consistent with findings in Ianchovichina and Martin (2001, 2002) and Wang (2002).

52 These are in 1997 US\$. This estimate is conservative since it does not reflect income increases due to trade-induced productivity gains, and especially gains associated with the liberalization of China's service sectors, as well as transaction cost savings. The benefits to China from developing institutions compatible with an open and modern market could be very large as well, but were not factored in the analysis.

${ }^{53}$ This estimate is in line with estimates in a wide range of studies, including Ianchovichina and Martin (2002), Li et al. (2000), Wang (2002), Deutsche Bank (2001). Results are sensitive to the values of the Armington elasticities of substitution, but do not change qualitatively. A fifty percent increase in the values of these elasticities almost doubles China's welfare gains from WTO accession, while a fifty percent reduction in the values of these elasticities reduces the gains to China by a factor of 10 .
} 
2a). ${ }^{54}$ As important suppliers of materials to China, these countries will observe an improvement in their terms of trade and returns to capital. In both Japan and the NIEs, the projected increases in production are driven mainly by expansion in exports to China. While these countries are well positioned to gain from accession, many of the trends from China's growing role are already underway.

Table 2a. Impact of China's WTO accession estimated with dynamic GTAP (cumulative volume changes relative to baseline for the period 2001-2010, US\$ millions)

\begin{tabular}{|c|c|c|c|c|c|c|c|c|c|c|}
\hline \multirow[b]{3}{*}{ Foodgrains } & \multicolumn{2}{|c|}{ Japan } & \multicolumn{2}{|c|}{ Tawain (China) } & \multicolumn{2}{|c|}{ Hong Kong (China) } & \multicolumn{2}{|c|}{ Korea } & \multicolumn{2}{|c|}{ Singapore } \\
\hline & \multirow{2}{*}{$\begin{array}{r}\text { Output } \\
-27\end{array}$} & Exports & Output & Exports & Output & Exports & Output & Exports & \multicolumn{2}{|c|}{ Output Exports } \\
\hline & & -3 & -91 & -20 & 0 & 0 & -8 & 1 & 0 & 0 \\
\hline Feedgrains & 5 & 0 & -32 & 1 & 0 & 0 & 12 & 0 & 0 & 0 \\
\hline Vegetables and fruits & -17 & -1 & -11 & -6 & 0 & 0 & 0 & 2 & 1 & 1 \\
\hline Oilseeds & 0 & 0 & -3 & 0 & 0 & 0 & 1 & 0 & 0 & 0 \\
\hline Sugar & -5 & 3 & -9 & -3 & 0 & 0 & 1 & 12 & -1 & -1 \\
\hline Plant fibers & 0 & 0 & 2 & -1 & 0 & 0 & 0 & 0 & 0 & 0 \\
\hline Livestock & -88 & -12 & -107 & 8 & 8 & 2 & -59 & -16 & 8 & 4 \\
\hline Beverages and tobacco & 1 & 7 & 3 & -4 & 64 & 64 & 1 & 5 & -1266 & -1283 \\
\hline Other food & -506 & -228 & -286 & 59 & -27 & -13 & -898 & -654 & -130 & -77 \\
\hline Wood products & 372 & 442 & 129 & 364 & 420 & 336 & 1007 & 827 & -13 & 33 \\
\hline Extractive & 29 & 21 & -8 & 21 & 17 & 0 & 14 & -6 & 2 & 16 \\
\hline Textiles & 2953 & 2838 & 5090 & 4180 & 339 & 826 & 3332 & 2951 & -77 & -77 \\
\hline Apparel & 865 & 214 & -343 & -121 & -2940 & -2953 & -377 & -394 & -89 & -90 \\
\hline Light manufactures & -15 & 6 & 101 & 87 & -3 & 4 & 23 & 57 & -2 & -2 \\
\hline Processing industry & 6294 & 5819 & 6543 & 5689 & 222 & 201 & 2242 & 1851 & -208 & -36 \\
\hline Autos & -6130 & -2411 & -2097 & 114 & -399 & 0 & -1739 & -334 & -223 & -143 \\
\hline Electronics & -1650 & 313 & 794 & 1296 & 512 & 498 & -1931 & -1710 & 371 & 370 \\
\hline Other manufactures & 1482 & 3043 & 228 & 843 & 1991 & 1885 & -1036 & -55 & 688 & 625 \\
\hline Total (GDP) (\%) & $-0 .($ & & 0.8 & 83 & 0 . & 10 & 0.0 & & -0.2 & \\
\hline Welfare (EV) & 189 & & 153 & 35 & 8 & 6 & 24 & & -14 & \\
\hline Rate of return (\%) & 0.0 & & 0.3 & 33 & 0 . & 18 & 0.1 & & 0.0 & \\
\hline Terms of trade $(\%)$ & 0.0 & & 0.3 & 38 & 0 . & 17 & 0.2 & & $-0 .($ & \\
\hline Foreign ownership (\%) & -0.5 & & 3.9 & 96 & 0. & 45 & 0.7 & & -0.4 & \\
\hline
\end{tabular}

Source: Authors' simulations with dynamic GTAP.

* Japanese welfare increase despite a decline in real GDP relative to the baseline due to increases in income from Japanese investments abroad.

Japan, Taiwan (China), Korea, and Hong Kong (China) are expected to raise their output of textiles in response to increased demand from China's expanding apparel industry (Table 2a). Their own garment industries will be squeezed, however, particularly in the markets where the quotas on Chinese textile and apparel exports are removed-North America and the European Union. The growth of their textile exports to the Philippines, Vietnam, India, and other South and Southeast Asian economies is also expected to drop,

\footnotetext{
${ }^{54}$ These results from CGE modeling are consistent with findings of other CGE modeling work. See Wang (2002), Ianchovichina and Martin (2002), Li et al. (2000), Deutsche Bank (2001). We find that Singapore loses from China's WTO accession. This finding should be interpreted with some care since our analysis takes into account only liberalization of cross-border trade in services. If we had taken into account the full package of reforms affecting China's services sector, we might have found that Singapore, which is well positioned to provide financial, communications and other types of services to China's growing economy, would gain from accession.
} 
as these countries' garment industries contract in the face of competition with China in third markets.

China is expected to increase demand for metals and petrochemicals from Korea; electronics and other manufactures from Singapore; light manufactures, petrochemicals, machinery, equipment, and electronics from Taiwan (China); and metals, petrochemicals and other manufactures from Japan. In electronics, China will source its additional inputs from the countries that get the largest tariff reductions - the US, India and other South Asian countries, and to a lesser extent Hong Kong (China) and Singapore - rather than from Korea, tariffs on whose electronic products are already quite low. ${ }^{55}$

In automobile production, China's current plans for restructuring its industry will make it a more efficient assembler of motor vehicles and eventually an exporter. ${ }^{56}$ This prospect could lead to a major reorganization of the industry across the region. Our analysis projects a contraction of automobile production in Japan and the NIEs.

The model does not capture the liberalization of China's service sectors. Though not captured here, the benefits to the NIEs from liberalization of China's services sectors is expected to be substantial. Accession is likely to increase demand for all types of services including transport and communications, which these economies are well positioned to provide. And it will enhance the role of Hong Kong (China) as a financial center serving the mainland's investment needs and providing investment services (Deutsche Bank, 2001).

China's WTO accession is unlikely to result in a decline in foreign investment flows into the NIEs (Table 2a). The returns to capital in these countries will rise relative to the baseline since the NIEs supply semi-finished materials to China, rather than compete with China, and hence their export prices will tend to rise. Our analysis suggests that with WTO accession China will increase its demand for petrochemicals, electronics, machinery, and equipment from Japan and the NIEs. New FDI investment is likely to flow into these expanding capital intensive sectors.

For Japan, the major impact from China's WTO accession is that China will become a more attractive destination for Japanese investments. After five years of strong growth, Japanese FDI to China dropped substantially in $1996-99,{ }^{57}$ less because of Japanese firms' financial difficulties than because of a difficult market environment in China. ${ }^{58}$ Some of the concerns about China's weak legal and administrative environment for foreign investment are likely to be addressed in line with WTO accession, although competition in markets for goods and services is expected to intensify.

\footnotetext{
${ }^{55}$ Differences in tariff cuts reflect differences in export composition by exporting country.

${ }^{56}$ Francois and Spinanger (2002).

${ }^{57}$ Ministry of Finance, Japan.

${ }^{58}$ Marukawa (2001).
} 
China's trade liberalization and growth will have a mixed impact on the developing countries in East Asia. While China's market presents sizeable opportunities for East Asian exporters, a few sectors - most notably apparel and textiles, are likely to face adjustments.

China's growing import demand gives these economies scope for expanding their agroprocessing, electronics, and other manufacturing industries such as machinery and equipment (Table 2b). Demand from China will be compounded by increased import demand from China's closest trading partners - Japan, NIEs, the EU and the US, which themselves will benefit from China's growth and WTO accession. And, given China's agricultural reforms, there is scope for expansion of agricultural exports to China such as oilseeds and sugar as well as basic raw materials such as timber and energy products.

Table 2b. Impact of China's WTO accession estimated with dynamic GTAP (cumulative volume changes relative to baseline for the period 2001-2010, US\$ millions)

\begin{tabular}{|c|c|c|c|c|c|c|c|c|c|c|}
\hline & \multicolumn{2}{|c|}{ Indonesia } & \multicolumn{2}{|c|}{ Vietnam } & \multicolumn{2}{|c|}{ Malaysia } & \multicolumn{2}{|c|}{ Philippines } & \multicolumn{2}{|c|}{ Thailand } \\
\hline & Output & Exports & Output & Exports & Output & Exports & butput & Exports & Output & Exports \\
\hline Foodgrains & -14 & 5 & 21 & 11 & 19 & 0 & 31 & 14 & -11 & -6 \\
\hline Feedgrains & 147 & 2 & 0 & -1 & 4 & 1 & 22 & 5 & 1 & 2 \\
\hline Vegetables and fruits & -19 & -1 & 0 & 1 & -11 & 5 & -9 & 10 & -9 & 0 \\
\hline Oilseeds & -3 & 0 & 0 & 0 & 0 & 0 & 0 & 0 & -1 & 0 \\
\hline Sugar & -9 & 1 & 2 & 1 & -7 & -4 & 10 & 8 & -9 & -5 \\
\hline Plant fibers & -18 & 0 & 0 & 0 & -3 & 0 & -4 & 2 & 53 & 0 \\
\hline Livestock & -23 & 0 & 1 & 1 & 64 & 47 & -4 & 1 & 0 & 0 \\
\hline Beverages and tobacco & -1 & 1 & -6 & -7 & 0 & -2 & 2 & 5 & -5 & -4 \\
\hline Other food & -116 & -78 & 32 & 28 & -74 & -51 & -2 & 10 & -55 & -45 \\
\hline Wood products & 478 & 373 & 5 & 4 & 418 & 315 & 16 & 17 & 36 & 59 \\
\hline Extractive & 68 & 123 & 5 & 14 & 47 & -1 & 4 & 11 & 7 & -4 \\
\hline Textiles & -660 & -470 & -61 & -13 & -204 & 198 & -297 & -85 & -972 & -301 \\
\hline Apparel & -1337 & -1164 & -990 & -1002 & -1015 & -1017 & -768 & -779 & -1094 & -1090 \\
\hline Light mnfcs & 234 & 236 & 91 & 101 & -3 & -3 & 26 & 25 & 12 & 16 \\
\hline Processing industry & 15 & 123 & 94 & 89 & 381 & 394 & -26 & 17 & 987 & 1126 \\
\hline Autos & -68 & -68 & -2 & -1 & -11 & 11 & -9 & -3 & -178 & -83 \\
\hline Electronics & 257 & 247 & 2 & 6 & 75 & 75 & 33 & 37 & 211 & 228 \\
\hline Other mnfcs & 67 & 65 & 21 & 20 & 133 & 138 & 19 & 25 & 213 & 280 \\
\hline Total (GDP) (\%) & & 0.2 & -0 & .4 & -0.1 & & -0. & .2 & -0 . & \\
\hline Welfare (EV) & & 52 & -3 & 36 & -14 & & -14 & 41 & -14 & \\
\hline Rate of return (\%) & & .07 & -0 . & 22 & -0.0 & & -0.0 & 04 & -0.0 & \\
\hline Terms of trade (\%) & & 02 & -0 . & 10 & 0.01 & & -0.1 & 14 & -0.0 & \\
\hline Foreign ownership (\%) & & 1.0 & -2 & .0 & -0.1 & & -0 & 8 & -0 . & \\
\hline
\end{tabular}

Source: Authors' simulations with GTAP-Dyn..

Wages of unskilled labor may come under pressure since the sectors that may come under pressure are more intensive in unskilled labor use, compared to those sectors that are set to expand. This implies that urban unemployment, inequality and vulnerability may worsen in the short run. The developing East Asian economies will need to invest in 
training of unskilled workers in order to facilitate the transition from textiles and clothing production to high end manufacturing.

The high intensity of trade between individual East Asian developing countries and China $^{59}$ in 2001 suggest that the planned reductions in the protection of China's markets offer some good opportunities for exporters in developing countries. At the same time, there is the threat of increased competition in third country markets from increased exports from China. The garment and textile sectors pose particular challenges. Once quotas on Chinese textile and apparel exports to North American and Western European markets are lifted in 2005, ${ }^{60}$ apparel exports from Malaysia, the Philippines, Thailand, Indonesia, and Vietnam will be negatively affected (Table 2b). The textile industry in developing East Asian countries in general will also be hurt, though nearly not as much as apparel, since some of these countries will start exporting textiles to China and other NIEs.

The overall impact on developing countries' income is expected to be negative (Table 2b). ${ }^{61}$ The outcome for the developing countries in East Asia may differ depending on a number of factors including productivity gains in China (Figures 1 and 2), transaction cost savings, the speed of adjustment, and the response of policy makers. The impact of accession is expected to be limited compared to changes in the baseline since WTO accession is only a part of China's reform process (Appendix Tables A2 and A3).

It is difficult to quantify and assess qualitatively the net impact of China's WTO accession on East Asian developing countries' foreign investment flows. Our general equilibrium analysis suggests that accession will result in a decline of these countries' foreign investment relative to the baseline (Table 2b). Our analysis suggests that FDI will flow mostly into the developing economies' farm, timber, energy and other manufacturing sectors as WTO accession increases demand for these products in China.

However, these results, while capturing the effect of WTO accession on rates of return in the developing economies of East Asia, do not take into account all other factors, discussed in section 2, that tend to boost investment in these countries. Opportunities exist for ASEAN countries to participate in global production networks in manufacturing sectors such as electronics, machinery and equipment that are likely to expand with China's further integration into the global economy. The net effect of WTO accession on investment in developing East Asian economies is therefore mixed, and will at the end depend on the policy responses of individual countries.

\footnotetext{
${ }^{59} \mathrm{Ng}$ and Yeats (2002).

${ }^{60}$ Importing economies will be allowed to introduce special textile safeguards during the period 2005-2007, but these will be effective for only one year at a time.

${ }^{61}$ This is a consensus finding supported by Ianchovichina and Martin (2001), Deutsche Bank (2001), Ianchovichina and Walmsley (2002), Wang (2002). The results are not very sensitive to changes in the Armington elasticities. A 50 percent increase in the Armington elasticities leads to 21 percent increase in the welfare loss to the developing countries in East Asia, while a 50 percent increase in the same elasticities reduces the fall in welfare by 39 percent.
} 


\section{Impact of Accession Induced Productivity Gains in China}

Accession to the WTO is expected to produce significant benefits to China in terms of additional productivity growth generated by trade and investment reforms that are part of the accession agreement. There is uncertainty about the magnitude of the reform-induced productivity gains and their effect on individual sectors. However, consensus exists that China's commitments in services represent the most significant part of China's accession package (Mattoo, 2001), and will generate sizable productivity gains as foreign firms introduce world class technology and management expertise. It is also likely that foreign investment in high-end manufacturing will boost productivity in these sectors.

Given the importance of these accession induced productivity gains, we evaluate the impact on the rest of East Asia of the following scenarios: ${ }^{62}$ (i) a positive productivity shock in China's service sectors; (ii) a positive productivity shock in China's high-end manufacturing sectors; ${ }^{63}$ and (iii) an economy-wide positive productivity shock in China. $^{64}$

We find that a percentage point increase in cumulative productivity growth in services by 2010 augments China's real GDP by 2.2 percent and China's welfare by US\$10 billion. The spillover effect of the productivity gain in services is substantial and China expands not only its services sectors, but also its high-end manufacturing industries which use services as intermediate inputs (Figure 1). China's industry structure shifts away from land and labor intensive products and low-end manufacturing which benefits Vietnam and Indonesia (Figure 2) as their losses from China's entry to the WTO accession are associated primarily with the removal of quotas for Chinese textile and apparel exports in North America and the European Union.

For the rest of the developing countries in East Asia, however, the good news for their light manufacturing and agricultural sectors does not translate into increases in welfare (Figure 2). The reason for this is that the industry structure of Korea, Malaysia, Thailand and the Philippines differs from that of Vietnam and Indonesia. Korea and the three Southeast Asian economies do not rely on agriculture, resources and light manufacturing exports as much as Vietnam and Indonesia do (Figure 3). Indeed, the share of high-end manufactures and commercial services in total exports is much higher for these countries than it is for Vietnam and Indonesia. Thus, by becoming a more efficient supplier of services, China grows to be a stronger competitor in products that are important exports for the relatively more advanced Southeast Asian economies. Similarly, the NIEs, which

\footnotetext{
${ }^{62}$ We look at the impact of exogenous shocks to productivity growth. There are not many studies on China's WTO accession that employ endogenous productivity growth models. A recent paper by Claro (2001) looks at the impact that FDI coming to China as a result of its WTO accession will have on China's economy. His approach could be very useful for looking at the impact of trade liberalization on services, but at present this work does not take into account the abolition of quotas on textiles and clothing, uses unreliable tariff data, and focuses only on FDI issues in manufacturing, whereas the important FDI issues concern services.

${ }^{63}$ These sectors are the processing industry, electronics, machinery and equipment.

${ }^{64}$ For comparison purposes the experiments are designed in a way which leads to the same increase in real GDP.
} 
rely heavily on exports of high-end manufactures and services, also lose as complementarities between China and the NIEs diminish with the improved efficiency of China's service sectors (Figure 2).

An increase in productivity of China's high-end manufacturing sectors leads to similar outcomes. The difference is only in the extent of the changes. China's high-tech manufacturing sectors expand more, while its apparel, textile and services sectors expand less than they do in the case of increased productivity in services (Figure 1). Vietnam and Indonesia will benefit even more than they do in the case of increased productivity in services (Figure 2) since the complementarities with the Chinese economy have increased further with China becoming a more efficient producer of high-end manufactures. For the NIEs and the more advanced Southeast Asian economies a more efficient high-end manufacturing in China implies more competition in high-end manufactures which comprise a large share of their exports. Consequently, these countries are not as well off as they are in the case of a productivity increase in services (Figure 2).

Finally, a comparison of these two cases with the case of a uniform productivity growth ${ }^{65}$ suggests that Vietnam and Indonesia will benefit the most if China's economy becomes more efficient in the production of high-end manufactures. In contrast, the most favorable outcome for the more advanced Southeast Asian economies and the NIEs is for China to continue to specialize in labor-intensive products.

\footnotetext{
${ }^{65}$ The comparison allows us to evaluate the effect of productivity growth in the absence of an income effect and therefore to capture the 'pure' effect of a sector-specific productivity growth on the industry structure.
} 
Figure 1. Output changes in China.

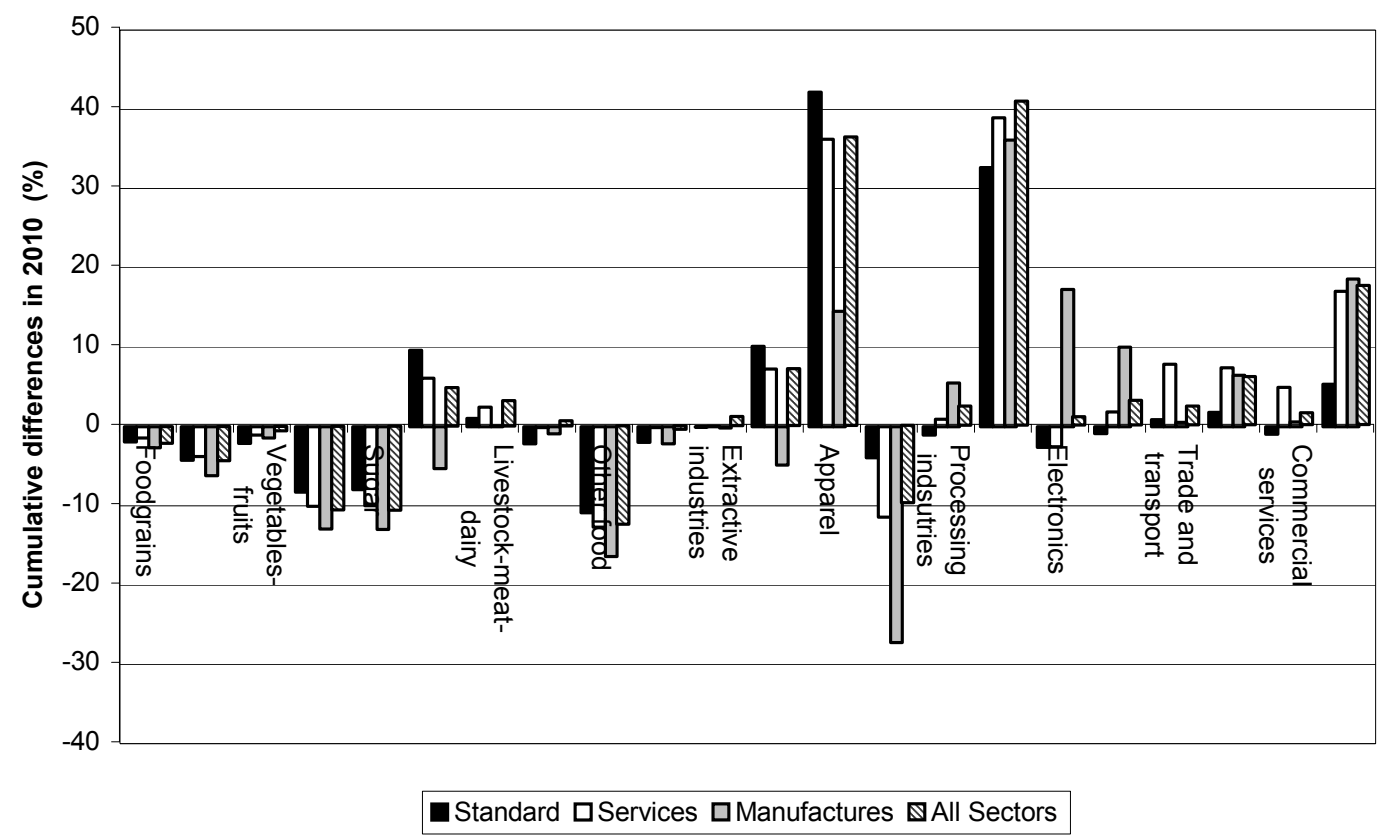

*Source: Authors' simulations with GTAP-Dyn. 'Standard' denotes results from the standard policy case with no productivity gains; 'Services' denotes the case of increased productivity in China's services; 'Manufactures' denotes the case of increased productivity in China's high-end manufactures; 'All sectors' denotes uniform productivity increase in China.

Figure 2. Cumulative welfare changes in 2010

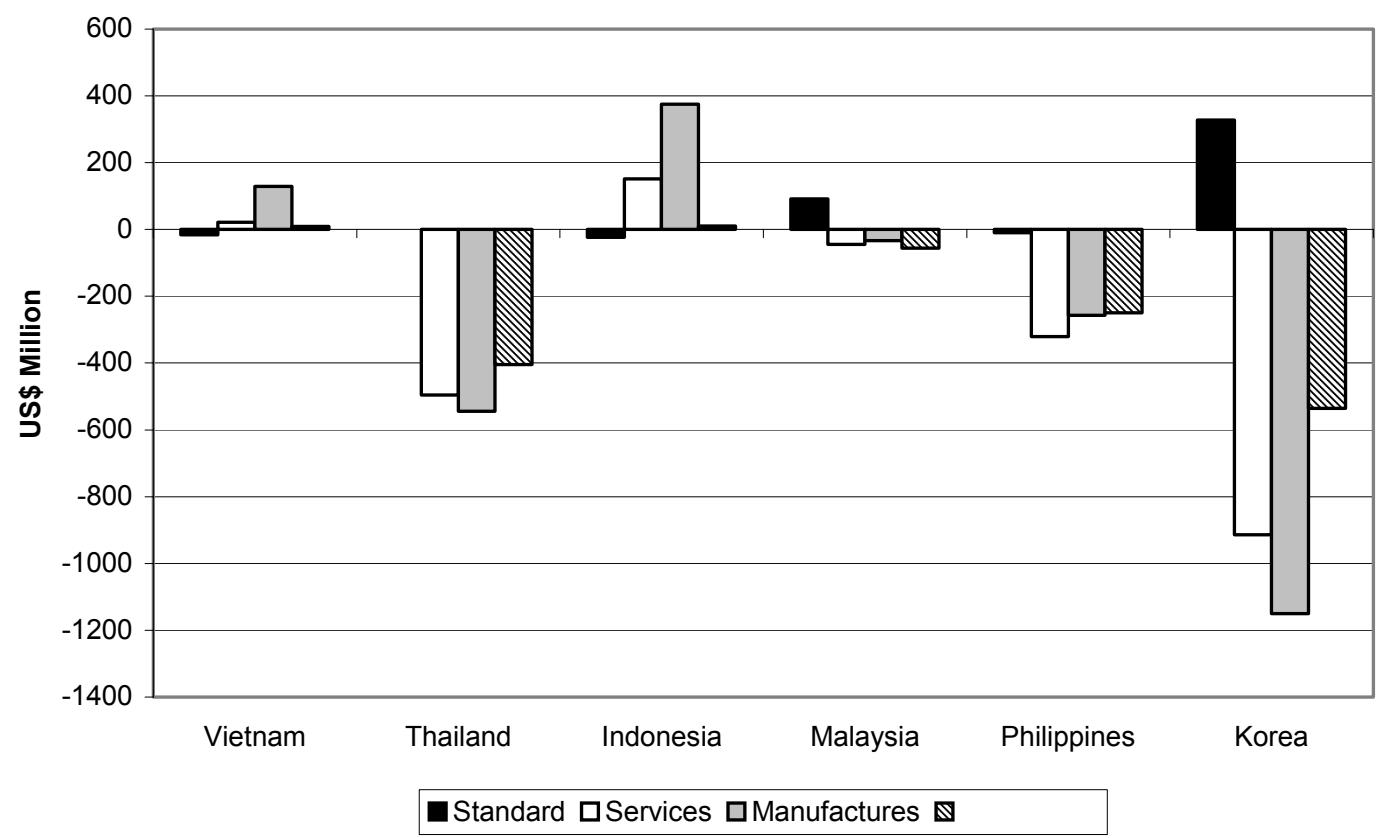

*Source: Authors' simulations with GTAP-Dyn (2002). 
Figure 3. Export shares for 1997

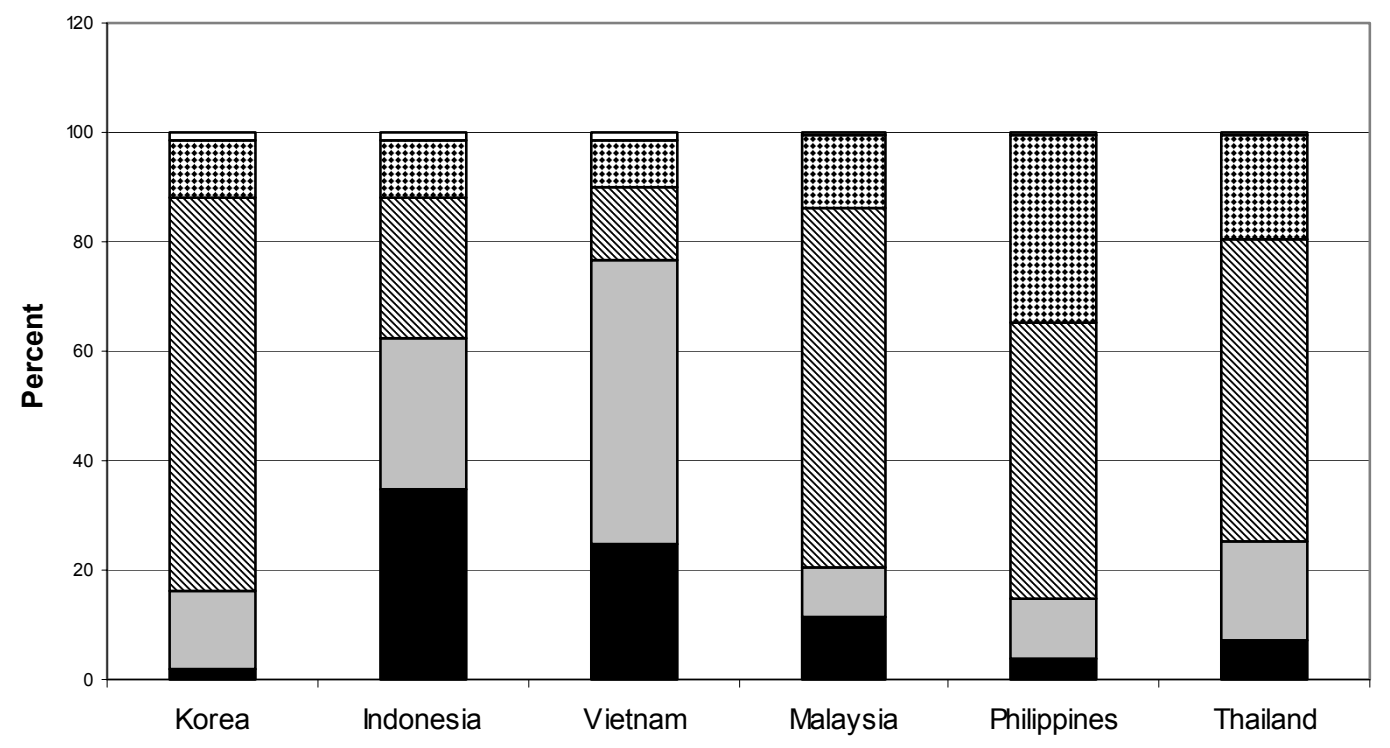

Agriculture $\square$ Light manufactures $\mathbb{\$}$ Other manufactures . Commercial services $\square$ Other services

*Source: Version 5 GTAP data base (Dimaranan and McDougall, 2002).

\section{Concluding remarks}

The task of assessing the impact of WTO accession on East Asia represents an enormous challenge. Given the wide range of actors both in China and abroad and the even wider range of complex interactions involved, one of the primary objectives of this paper was to present information in an organized fashion regarding those key aspects of China's accession which will affect East Asia.

We began with a qualitative assessment of the possible channels through which China's accession can affect economies in East Asia. We then proceeded to quantify these effects using a dynamic computable general equilibrium (CGE) model. The results indicate that China will be the biggest beneficiary of accession to the WTO, and that most of the benefits are associated with China's own trade liberalization. While industrialized and newly industrialized countries in East Asia will also largely benefit from China's accession to the WTO, the benefits are small relative to the size of these economies and the vigorous growth projected to take place in the region over the next 10 years. By contrast, developing countries in East Asia are expected to incur small declines in real GDP and welfare as a result of China's accession, largely because China will become a more formidable competitor in areas such as apparel and textiles in which these countries have a comparative advantage.

Sectoral changes are important for understanding the individual country effects. With WTO accession China's output increases most significantly in those sectors where there 
is additional demand for exports - namely textiles, apparel and automobiles. Japan and the NIEs increase production in those sectors for which exports to China increase. Output of the textile and processing industries in Japan, Taiwan (China), Korea and Hong Kong (China) rises as a result of the increased demand for these products to be used as intermediate inputs in China.

The apparel industry in all developing East Asian economies is hurt as quotas on Chinese apparel and textiles in North America and Western Europe are removed. Over time, however, the South East Asian economies should overcome the negative impact on their apparel and textile sectors by expanding their processing, electronics and other manufacturing industries, largely in response to increased demand for these products from China and its closest trading partners.

China's accession to the WTO provides a powerful stimulus for investment in China. The reduction in tariffs raises the rate of return on Chinese capital relative to the baseline and relative to returns in other regions. For Japan, China becomes a more attractive destination for investment as with accession some of the concerns about China's weak business environment are likely to be addressed. The NIEs are unlikely to see a decline in investment flows as a result of China's WTO accession. These economies experience a rise in their rates of return to capital relative to the baseline because they are suppliers of raw materials to China rather than competitors.

Foreign investment in developing East Asian countries, however, is unlikely to rise as a result of China's WTO accession. The decline in returns to capital in these economies relative to the baseline imply that investors may be lured to China and other NIEs in search of better opportunities. Despite this result, it may be premature to conclude that the net impact of China's WTO accession on East Asian developing countries' foreign investment flows will be negative. The general equilibrium analysis does not take into account factors that may boost investment in these countries such as agglomeration effects and arrangements related to regional production networks. The net effect of WTO accession on investment in developing East Asian economies is therefore mixed, and will depend substantially on the policy response of individual countries.

The potential gains to China from accession to the WTO might be much larger than US $\$ 10$ billion. If with the inflow of foreign direct investment and trade liberalization Chinese firms adopt new technologies, develop institutions compatible with an open and modern market, and realize transaction cost savings, the gains to China could be several times larger. The countries' ability to change their import mix and the mix between domestic and imported goods is also directly related to the magnitude of China's welfare gains. The smaller the degree to which countries can alter this mix, the smaller the welfare gains to China.

As China becomes a more efficient supplier of services or a more efficient producer of high-end manufactures, its comparative advantage will shift away from labor-intensive products. This is good news for Vietnam, Indonesia and other developing countries with comparative advantage in these industries. However, it affects negatively the more advanced Southeast Asian countries and the NIEs as complementarities with China are 
reduced. Vietnam and Indonesia will benefit the most if China's economy becomes more efficient in the production of high-end manufactures. In contrast, the most favorable outcome for the NIEs is for China to continue to specialize in labor-intensive products.

While the analysis has built upon and improved earlier work, there are still areas that have been ignored. The analysis ignores non-tariff barriers in China's manufacturing sector other than the MFA quotas. This may not be a serious weakness since recent research suggests that NTBs in manufacturing have declined in importance. ${ }^{66}$ Oil was found to be the most important import item subject to any NTBs, and accounted for almost half the value of imports subject to any NTBs. Ferrous metals followed as the second most important category accounting for 30 percent of the value of imports subject to any NTBs.

The aggregation hides much of the variation in tariffs and the welfare gains from reducing this variation within product aggregates. The level of aggregation also hides important information on intra-industry trade in components as part of the production sharing arrangements that are very important in East Asia. This is a serious limitation especially when analyzing the impact on high-end manufacturing sectors such as electronics, autos, machinery and equipment. Therefore, the analysis presented here should be supplemented with sector specific case studies.

Finally, we found that, overall, the impact of China's WTO accession on the regional economies is small, but showed that trade-induced productivity gains could amplify these results substantially. There is also a consensus among institutional economist that transaction cost saving could also be substantial. ${ }^{67}$ Thus, this and other studies generally underestimate the impact of China WTO accession on China and the rest of East Asia.

\footnotetext{
${ }^{66}$ See Ianchovichina and Martin (2002) for further details.

${ }^{67}$ Based on comments by Lu Ding during Trade and Poverty Workshop, Institute of Southeast Asian Studies, September 20-21, 2002.
} 


\section{References}

Anderson, K., Huang, J. and Ianchovichina, E. (2002) 'Impact of China's WTO Accession on Agriculture and Rural-Urban Income Inequality,' paper presented at the Seminar on WTO Accession, Policy Reform and Poverty Reduction in China, World Bank, Beijing, June 28-29, 2002, and the Fifth Annual Conference on Global Economic Analysis, Taipei, Tawain (China), June 5-7, 2002.

Bhattasali, D. (2002), 'Strengthening Regulation of the Financial Sector,' presentation at the Seminar on WTO Accession, Policy Reform and Poverty Reduction in China, World Bank, Beijing, June 28-29, 2002.

Bhattasali, D., Shantong, L. and Martin, W. (2002) 'WTO Accession, Policy Reform and Poverty Reduction: An Overview,' paper presented at the Seminar on WTO Accession, Policy Reform and Poverty Reduction in China, World Bank, Beijing, June 28-29, 2002.

Chen, S. and Ravallion, M. (2002) 'Assessing the Impacts of Policy Reforms on Poverty,' presentation at the Seminar on WTO Accession, Policy Reform and Poverty Reduction in China, World Bank, Beijing, June 28-29, 2002.

Claro, S. (2001) 'Tariff and FDI liberalization: What to expect from China's entry into WTO?' paper presented at the eighth annual conference on empirical investigations in international trade, Purdue University, November 9-11,2001.

Deutsche Bank (2001) 'Quantifying the Impact of China's WTO Entry,' DB Global Market Research, 14 December, 2001.

Dimaranan, B. and McDougall, R. (2002). Global Trade, Assistance, and Production: The GTAP 5 Data Base, Center for Global Trade Analysis, Purdue University.

Fan, Z. and Li, S. (2000) 'The implications of accession to WTO on China's economy', paper presented at the Third Annual Conference on Global Economic Analysis, Monash University, Melbourne, Australia, June 28-30.

Finger, J. M. and Schuler, P. (2000) 'Implementation of Uruguay Round Commitments', in B. Hoekman (ed.), 'Developing Countries and the Next Round of WTO Negotiations', World Economy 23(4), pp. 511-26.

Francois, J. and Spinanger, D. (2002) 'The Motor Vehicle Sector in China and WTO Accession,' paper presented at the Seminar on WTO Accession, Policy Reform and Poverty Reduction in China, World Bank, Beijing, June 28-29, 2002.

Gilbert, J. and Wahl, T. (2001) 'Applied General Equilibrium Assessments of Trade Liberalization in China', Mimeo, Washington State University.

Hertel, T. W. (ed.) (1997) Global Trade Analysis: Modeling and Applications. Cambridge: Cambridge University Press. 
Hertel, T., Fan, Z., Wang, Z. (2002) 'Implications of WTO Accession for Poverty in China,' paper presented at the Seminar on WTO Accession, Policy Reform and Poverty Reduction in China, World Bank, Beijing, June 28-29, 2002.

Hertel, T. W., Walmsley, T. L. and Itakura, K. (2001) 'Dynamic Effects of the "New Age" Free Trade Agreement between Japan and Singapore,' Journal of Economic Integration, December, 16(4), pp.446-448.

Huang, J. and Rozelle, S. (2002) 'The Nature of Distortions to Agricultural Incentives in China and Implications of WTO Accession,' paper presented at the Seminar on WTO Accession, Policy Reform and Poverty Reduction in China, World Bank, Beijing, June 28-29, 2002.

Hussain, A. (2002) 'Coping and Adapting to Job Losses and Fall in Farm Earnings,' paper presented at the Seminar on WTO Accession, Policy Reform and Poverty Reduction in China, World Bank, Beijing, June 28-29, 2002.

Ianchovichina, E. (2003) 'GTAP-DD: A Model for Analyzing Trade Reforms in the Presence of Duty Drawbacks,' GTAP Technical Paper No. 21, http://www.agecon.purdue.edu/GTAP/techpapr/index.htm.

Ianchovichina, E. and Martin, W. (2001) 'Trade Liberalization in China's Accession to WTO,' Journal of Economic Integration 16(4), pp. 421-444.

Ianchovichina, E. and Martin, W. (2002) 'Economic Impacts of China's Accession to the WTO,' paper presented at the Seminar on WTO Accession, Policy Reform and Poverty Reduction in China, World Bank, Beijing, June 28-29, 2002.

Ianchovichina, E. and McDougall, R. A. (2001) 'Structure of Dynamic GTAP,' GTAP Technical Paper 17, Center for Global Trade Analysis, http://www.agecon.purdue.edu/GTAP/techpapr/index.htm.

IMF (1997) World Economic Outlook, IMF, and The World Bank, Washington, DC.

Lejour, A. (2000) 'China and the WTO: The Impact on China and the World Economy,' $\mathrm{CPB}$, the Netherlands Bureau for Economic Policy Analysis.

Li, S., Wang, Z., Fan, Z., Xu, L. (2000), WTO: China and the World, China Development Press, Beijing.

Maskus, K. (2001) 'Intellectual Property Rights in the WTO Accession Package: Assessing China's Reforms,' paper at the Workshop on WTO Accession, Policy Reform, and Poverty Reduction, The World Bank, Beijing, China, October.

Martin, W. (1993) 'The Fallacy of Composition and Developing Country Exports of Manufactures," World Economy 16(2):159-72. 
Martin, W. and Ianchovichina, E. (2001) 'Implications of China's Accession to the World Trade Organization for China and the WTO,' World Economy 24(9), September 2001.

Marukawa, T. (2001) 'Japanese Foreign Direct Investment and China's Industrial Development: Focusing on Automobile, Electronics, and Textile Industries,' paper presented at the conference on "Japan and China: Economic Relations in Transition", Tokyo, Japan, January 18-19, 2001.

Mattoo, A. (2001) 'China's Accession to the WTO: The Services Dimension,' paper presented at the Workshop on WTO Accession, Policy Reform, and Poverty Reduction, The World Bank, Beijing, China, October.

McKibbin, W. and Tang, K. (2000) 'Trade and Financial Reform in China: Impacts on the World Economy', World Economy 23(8), August 2000.

Messerlin, P. (2002) 'China in the WTO: Antidumping and Safeguard' paper presented at the Seminar on WTO Accession, Policy Reform and Poverty Reduction in China, World Bank, Beijing, June 28-29, 2002.

Ng, F. and Yeats, A. (2002) “Major Trade Trends in East Asia: What Are Their Implications for Regional Cooperation and Growth?” mimeo, World Bank.

Pangestu, M. and Mrongowius, D. (2002) 'Telecommunication services in China: Facing the Challenges of WTO Accession,' paper presented at the Seminar on WTO Accession, Policy Reform and Poverty Reduction in China, World Bank, Beijing, June 28-29, 2002.

Sicular, T. and Zhao, Y. (2002) 'Employment, Earnings and Poverty in Rural China: A Microeconomic Analysis,' paper presented at the Seminar on WTO Accession, Policy Reform and Poverty Reduction in China, World Bank, Beijing, June 28-29, 2002.

Spinanger, D.(1999) 'Textiles beyond the MFA Phase-Out,' World Economy 22(4), pp.455-76, June.

UNCTAD (2001) World Investment Report 2001: Promoting Linkages, UNCTAD, Geneva.

Walmsley, T. L. and Hertel, T. W. (2001) "China's Accession to the WTO: Timing is Everything”, World Economy 24(8), pp. 1019-49, August.

Walmsley, T., Hertel, T. and Ianchovichina, E. (2001) 'Assessing the Impact of China's WTO Accession on Foreign Ownership', Paper presented at the Fourth Annual Conference on Global Economic Analysis, Purdue University, Indiana, June 27-29.

Wang, Z. (2002) 'WTO Accession, "Greater China” Free Trade Area and Economic Relations across the Taiwan Strait,' paper presented at the Fifth Conference on Global Economic Analysis, Taipei, June 5-7, 2002. 
Wenping, L. and Finlday, C. (2002) 'Logistics in China: Accession to the WTO and its Implications,' paper presented at the Seminar on WTO Accession, Policy Reform and Poverty Reduction in China, World Bank, Beijing, June 28-29, 2002.

World Bank (1997) China Engaged: Integration with the Global Economy, The World Bank, Washington, DC. 


\section{Appendix}

Table A1. List of Countries and Commodities in the Study

\begin{tabular}{ll}
\hline Regions & Sectors/Commodities \\
\hline Australia & Foodgrains: paddy rice, processed rice, wheat \\
New Zealand & Feedgrains: cereals other than rice and wheat \\
North America: USA and & Vegetables and fruit: vegetables, fruits, nuts \\
Canada & \\
Western Europe: EU, EFTA & Oilseeds: Oil seeds \\
Japan & Sugar: Sugar cane, sugar beet, sugar \\
China & Plant fibers: plant-based fibers incl. cotton \\
Tawain (China) & Livestock Meat and Dairy: Cattle, sheep, goats, horses, animal \\
& products, raw milk, wool, silk-worm cocoons, meat, meat \\
Hong Kong (China) & products, dairy products \\
Korea & Beverages and tobacco: Beverages and tobacco \\
& Other food: Fishing, vegetable oils and fats, other food \\
Singapore & products \\
Indonesia & Wood products: Forestry, wood products, paper products \\
Vietnam & Extract: Coal, oil, gas, other minerals \\
Malaysia & Textiles: Textiles \\
Philippines & Wearing apparel: Wearing apparel \\
Thailand & Light manufacturing: Leather products and light manufactures \\
India & Processing industries: Chemical, rubber, plastic products, \\
Other South Asia & mineral products, metals, and metal products \\
Mexico & Autos: Motor vehicles and parts \\
& Electronics: Electronic equipment \\
Other Latin America & Other manufactures: Transport equipment nec, machinery and \\
Rest of World & Trade and transport: Trade and transport \\
& Communications: Communications \\
& Commercial services: Financial and business services, \\
& insurance \\
& Other services: Public Admin/Defense/Health/Education, \\
& Recreation and other services, Dwellings \\
\hline
\end{tabular}


Table A2. Baseline projections of annual real GDP growth rates (\%)

\begin{tabular}{lcccccccccccccc}
\hline & 1998 & 1999 & 2000 & 2001 & 2002 & 2003 & 2004 & 2005 & 2006 & 2007 & 2008 & 2009 & 2010 \\
\hline Australia & 5.3 & 4.7 & 3.8 & 2.0 & 2.8 & 2.9 & 3.6 & 3.5 & 3.2 & 3.4 & 3.2 & 3.4 & 3.4 \\
New Zealand & 0.0 & 4.4 & 3.6 & 1.8 & 1.9 & 4.0 & 3.3 & 2.5 & 2.3 & 2.8 & 3.0 & 3.2 & 3.2 \\
North America & 4.3 & 4.2 & 4.2 & 1.1 & 1.1 & 3.8 & 3.6 & 2.7 & 2.7 & 2.7 & 2.7 & 2.7 & 2.7 \\
Western Europe & 2.8 & 2.5 & 3.4 & 1.5 & 1.4 & 3.7 & 2.7 & 2.2 & 2.3 & 2.5 & 2.7 & 2.7 & 2.7 \\
Japan & -1.1 & 0.8 & 1.5 & -0.8 & 0.1 & 2.4 & 3.0 & 2.2 & 2.4 & 2.9 & 2.8 & 2.5 & 2.2 \\
China & 7.8 & 7.1 & 8.0 & 7.2 & 6.5 & 8.3 & 8.0 & 7.4 & 7.3 & 7.0 & 7.4 & 7.4 & 7.4 \\
Tawain (China) & 4.6 & 5.4 & 6.0 & 0.5 & 4.6 & 6.0 & 5.5 & 4.9 & 4.7 & 4.6 & 4.6 & 4.0 & 3.3 \\
Hong Kong (China) & -5.3 & 3.0 & 10.5 & 2.0 & 2.7 & 5.5 & 6.4 & 4.3 & 4.5 & 5.2 & 4.8 & 4.2 & 4.2 \\
Korea & -6.7 & 10.9 & 8.8 & 2.5 & 3.6 & 5.6 & 5.5 & 5.2 & 4.8 & 5.0 & 5.1 & 4.9 & 4.8 \\
Singapore & 0.4 & 5.8 & 9.9 & -2.3 & 1.7 & 8.4 & 5.2 & 5.7 & 6.4 & 4.4 & 4.7 & 3.4 & 3.4 \\
Indonesia & -13.4 & 0.5 & 5.2 & 3.6 & 3.7 & 4.3 & 4.8 & 3.4 & 3.8 & 4.5 & 4.7 & 4.7 & 5.1 \\
Vietnam & 4.4 & 4.4 & 5.0 & 5.5 & 5.5 & 5.5 & 5.5 & 5.5 & 5.5 & 5.5 & 5.5 & 5.5 & 5.5 \\
Malaysia & -7.4 & 6.1 & 8.3 & 1.0 & 3.5 & 6.1 & 7.9 & 6.3 & 5.1 & 5.8 & 6.7 & 6.8 & 6.1 \\
Philippines & -0.6 & 3.4 & 4.0 & 2.2 & 3.1 & 5.6 & 6.0 & 4.5 & 3.6 & 3.9 & 4.0 & 3.8 & 4.1 \\
Thailand & -10.8 & 4.2 & 4.4 & 1.2 & 2.8 & 5.3 & 6.2 & 4.1 & 4.0 & 5.5 & 5.7 & 5.2 & 4.9 \\
India & 6.8 & 6.5 & 5.2 & 4.5 & 5.5 & 5.6 & 5.4 & 5.6 & 5.3 & 5.5 & 5.7 & 5.6 & 5.4 \\
Other South Asia & 3.7 & 3.8 & 4.0 & 4.7 & 4.9 & 5.2 & 5.4 & 4.9 & 5.1 & 5.2 & 5.3 & 5.3 & 5.4 \\
Mexico & 4.9 & 3.8 & 6.9 & 0.6 & 2.5 & 6.3 & 3.9 & 4.0 & 3.7 & 4.7 & 3.9 & 4.1 & 3.9 \\
Other Latin America & 1.5 & -0.6 & 3.1 & 1.0 & 2.5 & 4.0 & 4.2 & 3.5 & 3.6 & 4.0 & 4.0 & 3.8 & 3.7 \\
Rest of World & 1.4 & 2.5 & 4.9 & 2.6 & 2.9 & 4.1 & 3.9 & 3.2 & 3.3 & 3.7 & 3.6 & 3.6 & 3.5 \\
\hline Souce: Worl Bak
\end{tabular}

Source: World Bank 
Table A3. Baseline projections of annual Gross Domestic Investment growth rates (\%)

\begin{tabular}{lccccccccccccc}
\hline & 1998 & 1999 & 2000 & 2001 & 2002 & 2003 & 2004 & 2005 & 2006 & 2007 & 2008 & 2009 & 2010 \\
\hline Australia & 5.66 & 4.8 & 3.4 & 3.0 & 4.1 & 4.1 & 4.7 & 4.6 & 4.3 & 4.5 & 4.3 & 4.4 & 4.5 \\
New Zealand & -1.9 & 5.3 & 5.4 & 3.5 & 3.4 & 5.4 & 4.7 & 3.9 & 3.6 & 4.1 & 4.4 & 4.6 & 4.6 \\
North America & 6.9 & 5.4 & 4.2 & 1.5 & 0.47 & 2.9 & 3.1 & 2.0 & 2.0 & 1.1 & 1.1 & 1.1 & 1.1 \\
Western Europe & 5.0 & 3.8 & 4.2 & 1.9 & 2.2 & 4.3 & 3.4 & 3.0 & 3.0 & 3.2 & 3.4 & 3.4 & 3.5 \\
Japan & -6.6 & -2.4 & 1.5 & -0.7 & 1.5 & 2.3 & 2.7 & 2.1 & 2.4 & 2.8 & 2.7 & 2.4 & 2.1 \\
China & 11.2 & 8.7 & 7.9 & 7.2 & 6.9 & 8.7 & 8.5 & 7.8 & 8.0 & 7.7 & 8.0 & 8.0 & 8.0 \\
Tawain (China) & 3.1 & 5.9 & 7.0 & 1.4 & 5.2 & 6.7 & 6.2 & 5.6 & 5.4 & 5.3 & 5.3 & 4.6 & 4.0 \\
Hong Kong (China) & -5.3 & 1.5 & 11.0 & 2.6 & 3.7 & 6.0 & 6.9 & 4.8 & 5.0 & 5.7 & 5.3 & 4.7 & 4.7 \\
Korea & -30.5 & 4.9 & 8.6 & 2.8 & 4.6 & 6.6 & 6.0 & 5.7 & 5.2 & 5.5 & 5.6 & 5.4 & 5.3 \\
Singapore & -1.2 & 4.7 & 11.0 & -1.4 & 2.6 & 8.4 & 5.0 & 5.4 & 6.1 & 4.1 & 4.5 & 3.1 & 3.1 \\
Indonesia & -50.9 & -14.3 & -2.0 & 0.6 & 4.2 & 5.4 & 5.2 & 4.2 & 4.5 & 5.5 & 5.7 & 5.7 & 6.1 \\
Vietnam & 3.5 & 4.3 & 5.9 & 6.3 & 6.2 & 6.3 & 6.3 & 6.3 & 6.3 & 6.3 & 6.3 & 6.3 & 6.3 \\
Malaysia & -33.1 & -0.9 & 8.6 & 0.7 & 2.3 & 4.9 & 6.7 & 5.1 & 4.0 & 4.5 & 5.3 & 5.5 & 4.7 \\
Philippines & -10.0 & -3.4 & 1.8 & 2.0 & 2.4 & 5.1 & 5.5 & 4.1 & 3.2 & 3.5 & 3.6 & 3.4 & 3.7 \\
Thailand & -20.0 & -4.5 & 0.6 & 0.7 & 4.9 & 7.5 & 9.1 & 7.0 & 7.2 & 8.7 & 8.9 & 8.3 & 8.0 \\
India & 4.3 & 4.0 & 2.7 & 3.6 & 5.6 & 5.7 & 5.6 & 5.9 & 5.7 & 6.0 & 6.1 & 6.1 & 5.9 \\
Other South Asia & 2.3 & 4.2 & 4.9 & 5.3 & 5.6 & 6.0 & 6.3 & 5.5 & 5.7 & 5.8 & 5.8 & 5.9 & 5.9 \\
Mexico & 15.2 & 5.8 & 9.3 & 3.0 & 4.6 & 8.4 & 6.3 & 6.3 & 5.9 & 6.8 & 6.0 & 6.3 & 6.1 \\
Other Latin & & & & & & & & & & & & \\
America & 1.9 & -6.2 & 4.9 & 2.7 & 3.3 & 4.8 & 4.9 & 4.1 & 4.3 & 4.6 & 4.6 & 4.4 & 4.4 \\
Rest of World & -1.0 & 2.2 & 6.8 & 3.8 & 4.1 & 5.4 & 5.3 & 4.5 & 4.7 & 5.1 & 5.0 & 5.0 & 5.0 \\
\hline Source: Word $B a n$
\end{tabular}

Source: World Bank. 